\title{
Belliella pelovolcani sp. nov., isolated from a mud- volcano in Taiwan
}

\author{
A. B. Arun, ${ }^{1}$ Chiu-Chung Young, ${ }^{1}$ Wen-Ming Chen, ${ }^{2}$ Mei-Hua Hung, ${ }^{1}$ \\ Wei-An Lai, ${ }^{1}$ Jui-Hsing Chou, ${ }^{1}$ P. D. Rekha, ${ }^{1}$ Fo-Ting Shen ${ }^{1}$ \\ and Shiawhwa Paul $\mathrm{Su}^{1}$ \\ ${ }^{1}$ College of Agriculture and Natural Resources, Department of Soil and Environmental Sciences, \\ National Chung Hsing University, Taichung 402, Taiwan, ROC \\ ${ }^{2}$ Laboratory of Microbiology, Department of Seafood Science, National Kaohsiung Marine \\ University, Kaohsiung City 811, Taiwan, ROC
}

Correspondence

Shiawhwa Paul Su

spsu@dragon.nchu.edu.tw
During investigations on the biodiversity of bacteria associated with a rare mud-volcano (mud basin) located in Liyushan (Mt. Carp), Wandan Township, Pingtung County, Taiwan $\left[22^{\circ} 56^{\prime} \mathrm{N} 120^{\circ} 46^{\prime} \mathrm{E}\right.$; temperature, $38^{\circ} \mathrm{C}$; pH 8.2; alkalinity, $3.3 \mathrm{mM}$; Cl $13 \mathrm{mM}$; $\mathrm{SO}_{4} 1020 \mu \mathrm{M}$; Na $10 \mathrm{mM}$ (You et al., 2004)], strain CC-SAL- $25^{\mathrm{T}}$ was isolated and maintained on marine agar 2216 (MA; Difco) after incubation at $37{ }^{\circ} \mathrm{C}$ for $48 \mathrm{~h}$. Subcultivation was done on $\mathrm{MA}$ at $37{ }^{\circ} \mathrm{C}$ for $2-3$ days. On this medium, strain CCSAL- $25^{\mathrm{T}}$ was able to grow at $25-40{ }^{\circ} \mathrm{C}$, but not at 45 or $20{ }^{\circ} \mathrm{C}$. The organism was able to grow on nutrient agar (NA; HI-MEDIA), R2A agar (Difco) and MacConkey agar (bioMérieux). Strain CC-SAL- $25^{\mathrm{T}}$ was preserved at $-80{ }^{\circ} \mathrm{C}$ in nutrient broth [marine broth (MB); Difco] with $20 \%$ $(\mathrm{v} / \mathrm{v})$ glycerol or by lyophilization.

Gram-staining was performed as described by Gerhardt et al. (1994). The presence of poly- $\beta$-hydroxybutyrate granule accumulation was assessed using light microscopy (Zeiss model A3000; $\times 1000$; Taiwan Instrument Co.) after the cells were stained with Sudan black. Phenotypic characteristics, biochemical tests, carbon source utilization (Biolog-GN), API ZYM enzyme profiles (bioMérieux), API 20E (bioMérieux), API 20NE (bioMérieux), API $50 \mathrm{CH}$ (bioMérieux) and ATB-PSE (bioMérieux) were investi-

The GenBank/EMBL/DDBJ accession number for the 16S rRNA gene sequence of strain CC-SAL-25 ${ }^{\top}$ is EU685336. gated. For the guanine-plus-cytosine $(\mathrm{G}+\mathrm{C})$ content calculations, a DNA sample was prepared and degraded enzymically into nucleosides as described by Mesbah et al. (1989). The nucleoside mixture obtained was then separated using high-performance liquid chromatography (HPLC). The G $+\mathrm{C}$ content of the DNA of strain CC-SAL$25^{\mathrm{T}}$ was $40 \pm 1$ mol\% (mean $\pm \mathrm{SD}$ ).

Cell morphology was observed by using light microscopy (Zeiss model A3000; $\times 1000$ ), with cells that had been grown for $48 \mathrm{~h}$ at $37{ }^{\circ} \mathrm{C}$ on MA. The results are given in the species description. The $\mathrm{pH}$ range for growth was determined by measuring the optical density (wavelength, $595 \mathrm{~nm}$ ) of a culture grown in $\mathrm{MB}$ that was adjusted prior to sterilization to various $\mathrm{pH}$ values ( $\mathrm{pH} 3-11$, at intervals of $0.5 \mathrm{pH}$ units) using appropriate biological buffers (Chung et al., 1995). Verification of the $\mathrm{pH}$ values after autoclaving revealed only minor changes. Growth at various temperatures $\left(10-55{ }^{\circ} \mathrm{C}\right)$ was measured in MB. Anaerobic growth was checked by using the Oxoid AnaeroGen system (Miller et al., 1995) in $\mathrm{MB}$. Growth was recorded by measuring the optical density $\left(\mathrm{OD}_{595}\right)$ of the culture with respect to time. Cellular pigments were extracted with acetone/methanol $(7: 2, \mathrm{v} / \mathrm{v})$, from cultures grown on MA and the absorption spectra were determined with a scanning UV/visible spectrophotometer (Hitachi; Japan). The presence of flexirubin-type pigments was investigated as described by Reichenbach (1992) and Bernardet et al. (2002). 
The $16 \mathrm{~S}$ rRNA gene sequence of strain CC-SAL- $25^{\mathrm{T}}$ was determined and analysed as described previously (Young et al., 2005). Analysis of the sequence data was performed by using the software package MEGA (Molecular Evolutionary Genetics Analysis) version 2.1 (Kumar et al., 2001), after multiple alignments of data using CLUSTAL_X (Thompson $e t$ al., 1997). A distance matrix method (distance options according to the Kimura two-parameter model), including clustering by neighbour-joining (Fig. 1), and a discretecharacter-based maximum-parsimony method were used. In each case bootstrap values were calculated based on 1000 replications. The 16S rRNA gene sequence of strain CCSAL- $25^{\mathrm{T}}$ obtained was a continuous stretch of $1444 \mathrm{bp}$. Sequence similarity calculations indicated that strain CCSAL- $25^{\mathrm{T}}$ showed greatest similarity to the species Belliella baltica (95.4\%; GenBank accession no. AJ564643), which to-date is the only recognized species in the genus Belliella (Brettar et al., 2004) in the Cytophaga-FlavobacteriumBacteroides group, whereas lower sequence similarities
$(<94.5 \%)$ were found with all other species shown in Fig. 1.

Fatty acid methyl esters were prepared, separated and identified according to the instructions of the Microbial Identification System (MIDI; Microbial ID). The fatty acid profile of strain CC-SAL- $25^{\mathrm{T}}$ was consistent with that reported for B. baltica BA134 ${ }^{\mathrm{T}}$ (Brettar et al., 2004), but the amounts of the fatty acids iso- $\mathrm{C}_{15: 1} \mathrm{G}$, iso- $\mathrm{C}_{15: 0}$ and $\mathrm{C}_{15: 1} \omega 6 c$ differed (Table 1 ).

Respiratory quinones of strain CC-SAL- $25^{\mathrm{T}}$ were extracted, separated and identified as described by Minnikin et al. (1984) and analysed by HPLC as described by Collins \& Jones (1980). A menaquinone with seven isoprene units (MK-7) was the predominant respiratory quinone.

DNA-DNA relatedness experiments were not carried out between strain CC-SAL-25 $5^{\mathrm{T}}$ and its closest phylogenetic neighbour B. baltica $\mathrm{BA} 134^{\mathrm{T}}$ as the level of $16 \mathrm{~S}$ rRNA gene

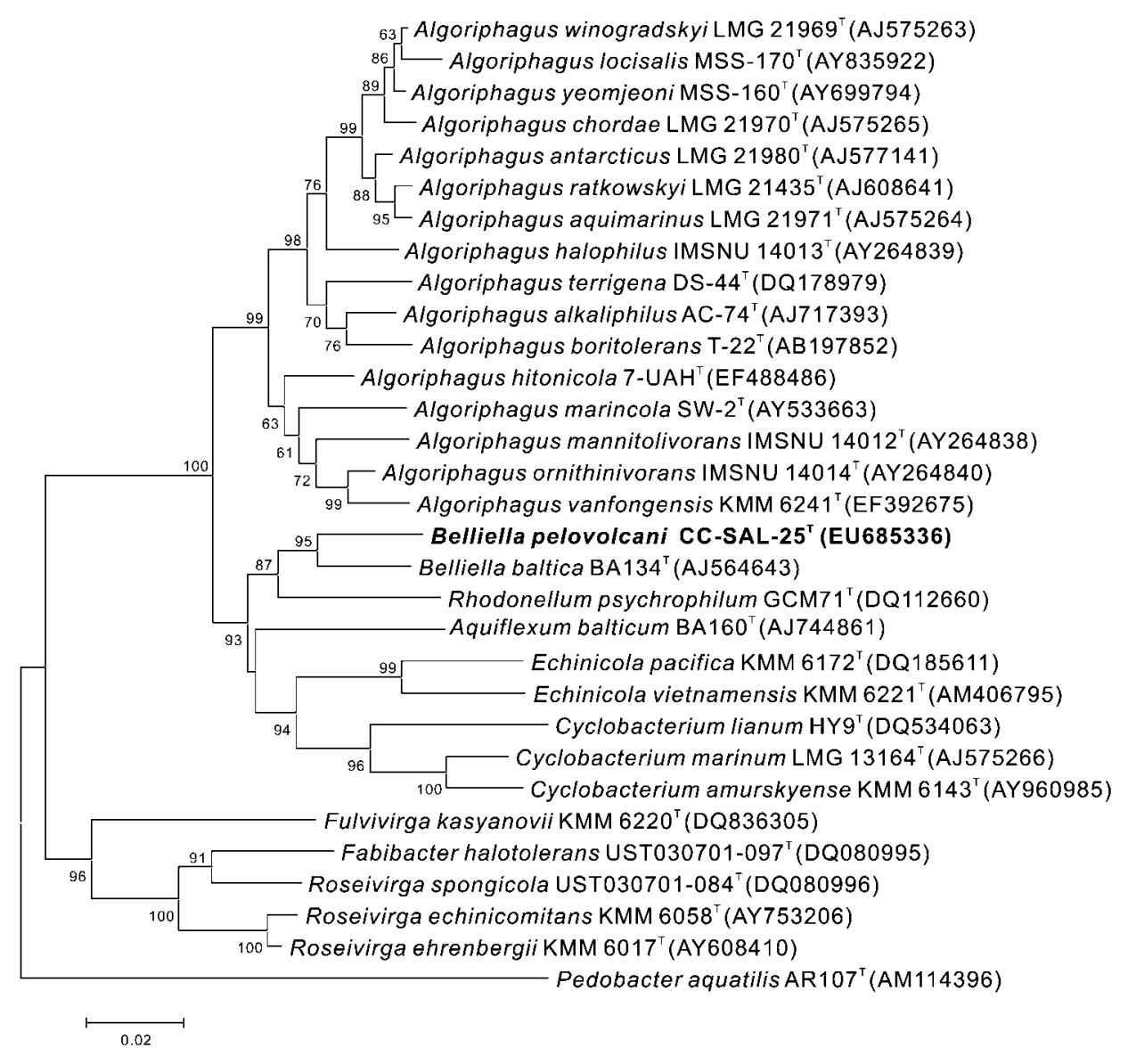

Fig. 1. Phylogenetic analysis based on $16 \mathrm{~S}$ rRNA gene sequences available from the GenBank/EMBL/DDBJ databases (accession numbers are given in parentheses) constructed after multiple alignments of data by using CLUSTAL_X (Thompson et al., 1997). Distances (distance options according to the Kimura-2 model) and clustering with the neighbour-joining method were performed by using the software package MEGA (Molecular Evolutionary Genetics Analysis) version 2.1 (Kumar et al., 2001). Percentage bootstrap values based on 1000 replications are given at branch points. Bar, 0.02 nucleotide substitutions per nucleotide position. 
Table 1. Fatty acid compositions of strain CC-SAL- $25^{\top}$ and B. baltica BA134

Strains: 1, CC-SAL-25 $5^{\mathrm{T}}$ (Belliella pelovolcani sp. nov.); 2, B. baltica $\mathrm{BA} 134^{\mathrm{T}}$ (data in parentheses are from Brettar et al., 2004). Both strains were grown on MA at $30{ }^{\circ} \mathrm{C}$ for $48 \mathrm{~h}$ (this study). Values are percentages of the total fatty acid content. Fatty acids of less than $0.5 \%$ are not shown. Values for predominant fatty acids are shown in bold. For unsaturated fatty acids, the position of the double bond is located by counting from the methyl $(\omega)$ end of the carbon chain. cis isomer is indicated by the suffix $c$. ND, Not determined.

\begin{tabular}{|c|c|c|}
\hline Fatty acid & 1 & 2 \\
\hline \multicolumn{3}{|c|}{ Saturated (straight-chain) } \\
\hline $\mathrm{C}_{13: 1}($ at $12-13)$ & 0.9 & $0.5(\mathrm{ND})$ \\
\hline $\mathrm{C}_{15: 0}$ & 0.5 & $0.7(3.8)$ \\
\hline $\mathrm{C}_{16: 0}$ & 1.5 & $1.2(\mathrm{ND})$ \\
\hline \multicolumn{3}{|l|}{ Saturated (branched) } \\
\hline iso- $\mathrm{C}_{17: 0}$ & 0.6 & $0.7(0.5)$ \\
\hline iso- $\mathrm{C}_{14: 0}$ & 1.3 & $0.7(1.8)$ \\
\hline iso- $\mathrm{C}_{15: 1} \mathrm{G}$ & 1.9 & $9.9(10.1)$ \\
\hline iso- $\mathrm{C}_{15: 0}$ & 31.2 & $23.9(18.9)$ \\
\hline iso- $\mathrm{C}_{16: 0}$ & 2.2 & $1.9(2.8)$ \\
\hline iso- $\mathrm{C}_{16: 1} \mathrm{H}$ & 1.7 & $2.9(3.2)$ \\
\hline anteiso- $\mathrm{C}_{15: 0}$ & 2.9 & $5.4(4.8)$ \\
\hline Summed feature $4^{*}$ & ND & $4.4(3.9)$ \\
\hline \multicolumn{3}{|l|}{ Unsaturated } \\
\hline $\mathrm{C}_{15: 1} \omega 6 \mathrm{c}$ & 6.4 & $1.2(2.5)$ \\
\hline $\mathrm{C}_{16: 1} \omega 5 \mathrm{c}$ & 4.2 & $4.9(2)$ \\
\hline $\mathrm{C}_{17: 1} \omega 6 \mathrm{c}$ & 7.9 & $5.6(9.8)$ \\
\hline $\mathrm{C}_{17: 1} \omega 8 \mathrm{c}$ & 1.1 & $1(1.5)$ \\
\hline iso- $\mathrm{C}_{17: 1} \omega 9 \mathrm{c}$ & 4.4 & $7.3(10.1)$ \\
\hline \multicolumn{3}{|l|}{ Hydroxy } \\
\hline $\mathrm{C}_{16: 0} 3-\mathrm{OH}$ & 2.5 & $1.9(\mathrm{ND})$ \\
\hline iso- $\mathrm{C}_{15: 0} 2-\mathrm{OH}$ & 1.2 & $0.9(0.9)$ \\
\hline iso- $\mathrm{C}_{15: 0} 3-\mathrm{OH}$ & 4.2 & $3.9(2.3)$ \\
\hline iso- $\mathrm{C}_{16: 0} 3-\mathrm{OH}$ & 1.1 & $0.7(\mathrm{ND})$ \\
\hline iso- $\mathrm{C}_{17: 0} 3-\mathrm{OH}$ & 6.7 & $5.2(3.0)$ \\
\hline Summed feature $3^{*}$ & 12.3 & $12.7(7)$ \\
\hline
\end{tabular}

* Summed features are groups of two or three fatty acids that cannot be separated by GLC with the MIDI system. Summed feature 3 contains one or more of the fatty acids $\mathrm{C}_{16: 1} \omega 7 c$ and iso- $\mathrm{C}_{15: 0} 2-\mathrm{OH}$. Summed feature 4 contains iso- $\mathrm{C}_{17: 1} \mathrm{~B} /$ iso I.

sequence similarity between the strains was less than $96 \%$, which is below the cutoff value $(97 \%)$ suggested by Stackebrandt \& Goebel (1994) for genomic distinction of species.

The results of the physiological characterization are given in the species description and in Table 2. Strain CC-SAL$25^{\mathrm{T}}$ was capable of producing acid from various carbohydrates, but carbon substrate oxidation tests with organic acids as substrates showed few positive results.

Strain CC-SAL- $25^{\mathrm{T}}$ could be differentiated from B. baltica $\mathrm{BA} 134^{\mathrm{T}}$, according to both phenotype (differential biochemical tests are given in Table 2) and genotype, and
Table 2. Genotypic, phenotypic and nutritional characteristics that distinguish strain CC-SAL-25 $5^{\top}$ (Belliella pelovolcani sp. nov.) from $B$. baltica BA134

Strains: 1, CC-SAL-25 $5^{\mathrm{T}}$ (Belliella pelovolcani sp. nov.); 2, B. baltica BA $134^{\mathrm{T}}$ (data from Brettar et al., 2004). +, Positive; -, negative; W, weakly positive.

\begin{tabular}{|c|c|c|}
\hline Characteristic & 1 & 2 \\
\hline Cell size $(\mu \mathrm{m})$ & $0.3 \times 2.0-5.0$ & $0.3-0.7 \times 1.5-3.0$ \\
\hline Colony colour & Pink/red & Pink/orange \\
\hline $\begin{array}{l}\text { Temperature range for growth } \\
\left({ }^{\circ} \mathrm{C}\right)\end{array}$ & $25-40$ & $4-37$ \\
\hline $\mathrm{pH}$ range for growth & $6-9$ & $6-10$ \\
\hline DNA G $+\mathrm{C}$ content $(\mathrm{mol} \%)$ & $40 \pm 1$ & 35.3 \\
\hline \multicolumn{3}{|l|}{ API $50 \mathrm{CH}$} \\
\hline D-Fructose & - & $\mathrm{W}$ \\
\hline D-Galactose & - & + \\
\hline D-Glucose & - & + \\
\hline $\begin{array}{l}\text { Methyl } \\
\alpha \text {-D-mannopyranoside }\end{array}$ & + & - \\
\hline Methyl $\alpha$-D-glucopyranoside & + & - \\
\hline$N$-Acetylglucosamine & + & - \\
\hline Amygdalin & + & - \\
\hline Arbutin & + & - \\
\hline Salicin & + & w \\
\hline Inulin & + & - \\
\hline Raffinose & + & $\mathrm{W}$ \\
\hline Glycogen & + & $\mathrm{w}$ \\
\hline Xylitol & + & - \\
\hline Gentiobiose & + & - \\
\hline Turanose & + & - \\
\hline D-Lyxose & + & - \\
\hline D-Tagatose & + & - \\
\hline D-Fucose & + & - \\
\hline L-Fucose & + & - \\
\hline D-Arabitol & + & - \\
\hline Potassium gluconate & + & - \\
\hline Potassium 2-ketogluconate & + & - \\
\hline Potassium 5-ketogluconate & + & - \\
\hline \multicolumn{3}{|l|}{ API $20 \mathrm{NE}$} \\
\hline Nitrate reduction to nitrite & - & + \\
\hline \multicolumn{3}{|l|}{ API ZYM } \\
\hline Esterase lipase & + & $\mathrm{w}$ \\
\hline
\end{tabular}

represents a second member of the genus Belliella, for which we propose the name Belliella pelovolcani sp. nov.

\section{Description of Belliella pelovolcani sp. nov.}

Belliella pelovolcani (pe.lo.vol.ca' ni. Gr. n. pelos mud; L. n. Volcanus god of fire, volcano; N.L. gen. n. pelovolcani of a mud-volcano, from which the type strain was isolated).

Cells are Gram-negative, aerobic, rod-shaped, non-motile and non-spore-forming, $2.0-5.0 \mu \mathrm{m}$ in length and $0.3 \mu \mathrm{m}$ in diameter. Good growth occurs after $48 \mathrm{~h}$ incubation on MA at $37{ }^{\circ} \mathrm{C}$. Colonies on marine agar at $37{ }^{\circ} \mathrm{C}$ are reddish/ pink-pigmented, smooth, shiny and convex with spreading 
edges, $1.0-2.0 \mathrm{~mm}$ in diameter and are non-fluorescent. Cellular pigments (red) present are carotenoids but not flexirubin. Optimal temperature for growth is $37{ }^{\circ} \mathrm{C}$. Optimal pH for growth is 8.0; growth occurs at $\mathrm{pH} 6.0$ 9.0 but not at $\mathrm{pH} 5.0$ or 10 . Growth occurs in the presence of $0.5-6 \%(\mathrm{w} / \mathrm{v}) \mathrm{NaCl}$; optimal growth occurs in the presence of $3 \%(\mathrm{w} / \mathrm{v}) \mathrm{NaCl}$. Does not grow anaerobically on MA supplemented with nitrate. Poly- $\beta$-hydroxybutyrate granules are not accumulated. Oxidase- and catalase-positive. Does not reduce nitrate to nitrite. The following carbon sources are oxidized (positive with the Biolog GN2 system): $\alpha$-cyclodextrin, dextrin, glycogen, Tween 40 , Tween 80 , Larabinose, cellobiose, i-erythritol, D-fructose, D-galactose, gentiobiose, $\alpha$-D-glucose, $\alpha$-D-lactose, lactulose, maltose, Dmannose, melibiose, methyl $\beta$-D-glucoside, D-psicose, raffinose, sucrose, trehalose, turanose, succinic acid monomethyl ester, acetic acid, L-alaninamide, L-alanine, L-alanyl glycine, L-glutamic acid, L-ornithine, L-threonine, inosine, uridine, thymidine, $\alpha$-D-glucose 1-phosphate and D-glucose 6-phosphate. The following substrates are not oxidized as carbon sources (negative with the Biolog GP2 system): $\mathrm{N}$ acetyl-D-galactosamine, $\mathrm{N}$-acetyl-D-glucosamine, adonitol, D-arabitol, L-fucose, myo-inositol, D-mannitol, L-rhamnose, D-sorbitol, xylitol, pyruvic acid methyl ester, cis-aconitic acid, citric acid, formic acid, D-galactonic acid lactone, Dgluconic acid, D-galacturonic acid, D-glucosaminic acid, Dglucuronic acid, $\alpha$-hydroxybutyric acid, $\beta$-hydroxybutyric acid, $\gamma$-hydroxybutyric acid, $p$-hydroxyphenylacetic acid, itaconic acid, $\alpha$-ketobutyric acid, $\alpha$-ketoglutaric acid, $\alpha$ ketovaleric acid, DL-lactic acid, malonic acid, propionic acid, quinic acid, D-saccharic acid, sebacic acid, succinic acid, bromosuccinic acid, succinamic acid, glucuronamide, Dalanine, L-asparagine, L-aspartic acid, glycyl L-aspartic acid, glycyl L-glutamic acid, L-histidine, hydroxy-L-proline, Lleucine, L-phenylalanine, L-proline, L-pyroglutamic acid, Dserine, L-serine, DL-carnitine, $\gamma$-aminobutyric acid, urocanic acid, phenylethylamine, putrescine, 2-aminoethanol, 2,3butanediol, glycerol and DL- $\alpha$-glycerol phosphate. In API $20 \mathrm{E}$ (bioMérieux), positive for $\beta$-galactosidase, $\mathrm{H}_{2} \mathrm{~S}$ production, citrate utilization, acetoin production and gelatinase. In API 20NE, positive for aesculin, gelatinase and $\beta$ galactosidase. In API ZYM, positive for alkaline and acid phosphatase, butyrate esterase, caprylate esterase (C8), leucine arylamidase, valine arylamidase, cystine arylamidase, trypsin, $\alpha$-chymotrypsin, naphthol-AS-B-1-phosphohydrolase, $\beta$-galactosidase and $\alpha$-glucosidase. Sensitive to the following antibiotics: ampicillin + sulbactam, ticarcillin, ticarcillin-clavulonic acid, piperacillin, piperacillin + tazobactam, cefepime, imipenem, meropenem, cotrimoxazole, ciprofloxacin; resistant to ceftazidime, amikacin, gentamicin, tobramycin and colistin (ATB-PSE 5). Additional phenotypic features are given in Table 2 . The detailed fatty acid profile is given in Table 1.

The type strain, CC-SAL- $25^{\mathrm{T}}\left(=\mathrm{BCRC} 17883^{\mathrm{T}}=\mathrm{KCTC}\right.$ $13248^{\mathrm{T}}$ ), was isolated from a mud-volcano in Taiwan.

\section{Acknowledgements}

This research work was kindly supported by a grant from National Science Council, Taiwan, and Council of Agriculture, EY, Taiwan. We thank W. S. Huang and S. Y. Lin for technical assistance.

\section{References}

Bernardet, J.-F., Nakagawa, Y. \& Holmes, B. (2002). Proposed minimal standards for describing new taxa of the family Flavobacteriaceae and emended description of the family. Int J Syst Evol Microbiol 52, 1049-1070.

Brettar, I., Christen, R. \& Höfle, M. G. (2004). Belliella baltica gen. nov., sp. nov., a novel marine bacterium of the CytophagaFlavobacterium-Bacteroides group isolated from surface of the central Baltic Sea. Int J Syst Evol Microbiol 54, 65-70.

Chung, Y. C., Kobayashi, T., Kanai, H., Akiba, T. \& Kudo, T. (1995). Purification and properties of extracellular amylase from the hyperthermophilic archeon Thermococccus profundus DT5432. Appl Environ Microbiol 61, 1502-1506.

Collins, M. D. \& Jones, D. (1980). Lipids in the classification and identification of coryneform bacteria containing peptidoglycans based on 2,4-diaminobutyric acid. J Appl Bacteriol 48, 459-470.

Gerhardt, P., Murray, R. G. E., Wood, W. A. \& Krieg, N. R. (editors) (1994). Methods for General and Molecular Bacteriology. Washington, DC: American Society for Microbiology.

Kumar, S., Tamura, K., Jakobsen, I. B. \& Nei, M. (2001). MEGA2: Molecular Evolutionary Genetics Analysis software. Bioinformatics 17, 1244-1245.

Mesbah, M., Premachandran, U. \& Whitman, W. B. (1989). Precise measurement of the $\mathrm{G}+\mathrm{C}$ content of deoxyribonucleic acid by high-performance liquid chromatography. Int J Syst Bacteriol 39, 159-167.

Miller, P. H., Wiggs, L. S. \& Miller, J. M. (1995). Evaluation of AnaeroGen system for growth of anaerobic bacteria. J Clin Microbiol 33, 2388-2391.

Minnikin, D. E., O’Donnell, A. G., Goodfellow, M., Alderson, G., Athalye, M., Schaal, A. \& Parlett, J. H. (1984). An integrated procedure for the extraction of bacterial isoprenoid quinones and polar lipids. J Microbiol Methods 2, 233-241.

Reichenbach, H. (1992). The order Cytophagales. In The Prokaryotes, 2nd edn, vol. 4, pp. 3631-3675. Edited by A. Balows, H. G. Trüper, M. Dworkin, W. Harder \& K. H. Schleifer. New York: Springer.

Stackebrandt, E. \& Goebel, B. M. (1994). Taxonomic note: a place for DNA-DNA reassociation and $16 \mathrm{~S}$ rRNA sequence analysis in the present species definition in bacteriology. Int $J$ Syst Bacteriol 44, 846-849.

Thompson, J. D., Gibson, T. J., Plewniak, F., Jeanmougin, F. \& Higgins, D. G. (1997). The CLUSTAL_X windows interface: flexible strategies for multiple sequence alignment aided by quality analysis tools. Nucleic Acids Res 25, 4876-4882.

You, C.-F., Gieskes, J. M., Lee, T., Yui, T.-F. \& Chen, H.-W. (2004). Geochemistry of mud volcano fluids in the Taiwan accretionary prism. Appl Geochem 19, 695-707.

Young, C.-C., Kämpfer, P., Shen, F.-T., Lai, W.-A. \& Arun, A. B. (2005). Chryseobacterium formosense sp. nov., isolated from the rhizosphere of Lactuca sativa L. (garden lettuce). Int J Syst Evol Microbiol 55, $423-426$. 